\title{
Preface
}

\section{Merold Westphal}

Two воOKs, Two visions of philosophy, two friends and sometime colleagues. Do we not have the makings of an exciting philosophical dialogue? Not quite. The crucial ingredient, as the Socrates of the Gorgias reminds us, is the willingness to enter into conversation, to abjure the making of speeches and to engage in open and honest question and answer without precondition. In this volume two contemporary philosophical postures, which, for the sake of convenience, can be labeled critical modernism and postmodernism, have been incarnated in persons who embody that crucial willingness to converse. While neither can be accused of passing up all opportunities to score rhetorical points, both have shown themselves passionately unwilling to reduce dialogue to playing games or to allow jargon to compromise the search for understanding.

This particular incarnation of the dialogue between critical modernism and postmodernism has a second remarkable asset. Readers of this volume and of the two books that lie behind it, Radical Hermeneutics and Post-Cartesian Meditations, will note with gratitude that Jack Caputo does not write like Derrida and Jim Marsh does not write like Habermas. Both have resisted the temptation to identify obscurity with profundity and have rather put in the service of their readers their ability to write lucid prose.

In seeking to make sense out of this debate it is important to keep in mind the political and philosophical common ground on which it is fought. Politically speaking, it takes place well to the left of center. Neither Caputo nor Marsh is willing to let the evils of state socialism or its collapse in eastern Europe blind him to the sufferings and injustices created and therefore tolerated by American society.

But the philosophical proximity that accounts for much of the heat generated by the disagreements that come to the fore is, if anything, more important. The shared presupposition of the present debate is the 
failure, to date at least, of the Enlightenment project. In an oft-quoted footnote to the First Edition Preface to the Critique of Pure Reason, Kant defines the key element of that project even better, perhaps, than in his famous essay, "What is Enlightenment?":

Our age is, in especial degree, the age of criticism, and to criticism, everything must submit. Religion through its sanctity, and lawgiving through its majesty may seek to exempt themselves from it. But then they awaken just suspicion, and cannot claim the sincere respect which reason accords only to that which has been able to sustain the test of free and open examination. [A xii]

It was the Enlightenment's intention to subject the prevailing social order to critical examination, and, in the process, to examine the theories, including theological theories, that provided its ideological justification. Thus, for example, John Locke directs a critique both at the political institution of absolute monarchy and at the divine right of kings theory that was often used to legitimate the former. The goal was a utopian one, as expressed in the title of Becker's classic, The Heavenly City of the Eighteenth-Century Philosophers, and in Hegel's summary of the Enlightenment dream, "The two worlds are reconciled and heaven is transplanted to earth below."

That sentence from Hegel's Phenomenology of Spirit is the immediate introduction to his analysis of the French Revolution, entitled "Absolute Freedom and Terror"' (VI, B, III). In it he argues that the Terror initiated by Robespierre revealed the intellectual bankruptcy of the Enlightenment in spite of its noble aspirations.

If critical modernism and postmodernism agree in a more general way with Hegel that the Enlightenment project has been unable to achieve its goals, it is not because they wish to return to precritical postures toward social structures and the theories that legitimate them. On the contrary, their goal is to preserve critique by rescuing it from those who gave it modern birth. Each seeks, in its own way, to reenact the Socratic union of radical critique, passionate commitment to reason, and epistemological humility.

For the two conflicting strategies embodied in this volume agree that the failure of the Enlightenment lies not in its critical goals but in an uncritical, arrogant view of reason that leaves it with pretensions to clarity and certainty that it cannot support. It was not that the Enlightenment thought there could be a critique of society without a corre- 
sponding critique of reason. The overwhelmingly epistemological character of modern philosophy bears witness to the fact that the Enlightenment was first and foremost a whole series of critiques of reason.

These critiques, from Descartes to Husserl and from Locke to logical positivism, were uncritical because they occurred in a historical context that specified a priori what the outcome must be. If reason was to stand in judgment on traditions and texts, institutions and practices that claimed for themselves the authority of the sacred, it would have to be sacred itself. It would have to be Reason, not merely reason. It would have to embody an Absolute Knowledge so completely unconditioned as to be, in the apt words of Thomas Nagel, "the view from nowhere."

Under this self-imposed pressure, the admission that it did not possess the whole of truth all at once was the extent of the humility possible to the Enlightenment. But it had to claim that it had access to pieces of the truth that were utterly clear and certain. This is the essence of the philosophical strategies now known as foundationalism. It is not the innocent claim that some of our beliefs rest on others, which play a foundational role in relation to the former. It is the stronger claim that some of our foundational beliefs can be final truths, pure pieces of cognitive gold, bits of Absolute Knowledge.

Critical modernism and postmodernism agree that all forms of foundationalism have failed, be they rationalist, empiricist, phenomenological, positivist, or whatever, and this in two senses. First, at the theoretical level, they cannot be defended. In the face of the many ways in which human knowledge is conditioned, the claims of this or that "piece" of knowledge to be unconditioned is at best unconvincing and at worst ludicrous. Second, at the practical level all forms of foundationalism embody the hubris that turns progress into pathology and liberation into terror. The adage of Lord Acton that "absolute power corrupts absolutely" is joined here by its corollary, "Absolute Knowledge corrupts absolutely."

So it is not surprising that Caputo begins his work by drawing heavily on Kierkegaard and Heidegger, while Marsh does the same with Merleau-Ponty. For these thinkers are among the most forceful of the many critics of foundationalism and its claims to Absolute Knowledge. 
Thus, beyond the agreement that we live in a society badly in need of critique, the critical modernism and postmodernism presented here agree that while foundationalism cannot ground critique because it is itself uncritical, philosophy must nevertheless be critique. The disagreement comes over the nature of postfoundationalist critique. Or perhaps it would be more precise to say that it is over the diagnosis of where foundationalism went wrong, since conflicting diagnoses underlie the competing attempts to redefine critique and thus to show how philosophical reflection can help us find the way to a better world.

Following Habermas, critical modernism finds the pathologies of modernity in the monological conception of reason that is its trademark. Beginning with Descartes, the subject has been conceived as seeking to penetrate and expose the object quite without essential relation to other subjects. The slogan "Think for yourself" came to mean "Think by yourself," and autonomy became inseparable from atomism.

Accordingly, critical modernism begins not with a theory of society (in the case of Marsh, a phenomenological Marxism) but with a theory of reason as dialogical. By seeking to specify (counterfactually) the conditions under which discourse about behavioral and institutional norms would be free of the distortion brought about by domination, it seeks to preserve a working concept of critical reason without having to claim possession of any final knowledge.

In spite of the just-mentioned disclaimer, postmodernism finds all this to be too optimistic about the power of human reason. Modernism appears as chastened in critical modernism, but insufficiently so. For by locating the problem in a monological concept of reason, it suggests that while I may not be able to grasp the Truth that Enlightenment opposed to tradition, We may not face the same obstacles that $I$ do. There may be no intrinsic barrier between us and the Truth. The voice of the people may be in principle the voice of God.

For Derrida (as for Kierkegaard before him), the radical finitude of human understanding is not affected by shifting focus from the $I$ to the We. Both the monological schemes of modernity and the dialogical strategies of critical modernism are insufficiently attentive to the systematic interdependence of absence and presence in any mode of awareness. Among the terms he uses to point to this structural feature of human understanding is différance. Part of the meaning of this strange word is that if intentions can never be completely fulfilled by 
means of the total presence of the intended, fullness of meaning must always be deferred to a future that will never become a present.

This may sound very much like Habermas, for whom the conditions of fully rational discourse always remain counterfactual, meaning that no actual understanding can be fixed or final, but is always subject to revision. Without doubt Habermasian dialogue and Derridean différance agree in pointing to the finitude of reason, the permanent impossibility of Absolute Knowledge. The challenge before the reader of this book is to sort out the difference between différance and dialogue and to find out what difference it makes.

While it is not the task of this preface to relieve the reader of that task before she has even had the chance to try it for herself, one clue may not be inappropriate. While the critical modernist concept of dialogue is prescriptive, the postmodern concept of différance is descriptive. The one tells us what we can do to be more nearly rational, while the other tells us about a condition from which we cannot escape, individually or collectively. Not surprisingly, critical modernism will seem to postmodernism to be so nearly as optimistic as modernism as to represent little more than repackaging of the Enlightenment; and postmodernism will seem to critical modernism so pessimistic as to have thrown out the baby of reason with the bath of Absolute Knowledge.

It is important to remember that much more is at stake than might at first be apparent in the sometimes abstract epistemological wrangling over such questions as whether the words "The truth is that there is no truth" represent important philosophical insight or the unpardonable philosophical sin. The modernity whose self-assurance is challenged throughout this volume includes Marxism-Leninism-Stalinism on the one hand and Adam Smith, John Locke, Thomas Jefferson, and James Madison on the other. While the Leninism of the Warsaw Pact nations is disintegrating in the face of economic failure, there is no shortage of opportunistic politicians and pundits in the West who are willing to gloat, more or less overtly, about this "vindication" of liberal society with its democratic and capitalistic institutions. But if modernity is mistaken when it holds the truths that legitimate liberal society to be self-evident, liberalism (in the classical sense of the term) may be as lacking in adequate foundations as Leninist society. If the Damoclean sword of Third World debt, the resurgence of racism, and the stubborn persistence of poverty, drugs, crime, and homelessness are taken as 
signs of an all too present crisis in the West, the problem of finding a cogent theoretical rationale for liberal society may seem a bit less "theoretical" than even philosophers are in the habit of thinking.

The basic question of this book, I believe, is what role critical reason can play in shaping and supporting a truly humane society. Even if in the heat of debate we sometimes forget it, it is the passion of that question that unites all of the contributors to this volume. We hope it will find readers who share that passion, who will benefit from our discussion, and who will make their own contributions to an ongoing conversation whose bearing on life in the "real world" may well be more direct than we suspect.

A word, finally, about chronology. This volume had its origin in a symposium held at Fordham University in March of 1989. The papers given by Marsh and Caputo, the responses by De Nys and Yount respectively, and some of the discussion that followed are included in this volume. These materials are preceded by Marsh's review of Radical Hermeneutics, which was written before the symposium, and by Caputo's review of Post-Cartesian Meditations, which was written later. In August of 1989, Caputo, Marsh, and I got together for the informal three-way conversation that appropriately follows the materials of the Fordham symposium in this volume. It was after that conversation that Caputo wrote his review of Marsh's book and I wrote my own response to the Fordham symposium, with reference to Cratylus. The final two items in this volume are the responses of Marsh and Caputo to this essay, dashing my hopes of having the last word.

Those of us who have engaged in this conversation have had more fun than philosophers should ever be permitted. But there has been a lot of hard work as well. We would especially like to thank Nemesio Que, S.J., Kathryn Shaughnessy, Cynthia Cruz, and Bruce Harasty for their expert help in transcribing taped material and in preparing the final manuscript. We would also like to thank the International Philosophical Quarterly for permission to reprint the reviews with which this volume begins. 


\section{MODERNITY \\ AND ITS \\ DISCONTENTS}


